\title{
Japan's health-care system rocked again
}

Japan's ministry of health and welfare finds itself immersed again in scandal at a time when the country's health-care system is in critical need of extensive reform to reduce escalating costs and to improve services. Nobuharu Okamitsu, who until last November was the ministry's most senior bureaucrat, was arrested in December for allegedly accepting 60 million yen (US\$526,000) in bribes from the head of a company that uses government subsidies to build nursing homes for the elderly, a rapidly growing segment of the Japanese population.

Hiroshi Koyama, head of the Aya Fukushi Group (the company at the center of the scandal), was arrested in November on suspicion of bribing another official at the health ministry (who was arrested
A new scandal: Nobuharu Okamitsu is arrested for accepting bribes. increasing by 4 percent (700,000 individuals) a year, which is pushing up health care costs by at least 5 percent annually. As a result, Japan's government-backed insurance schemes are running up large deficits.

In response to the looming crisis, an influential government advisory panel called last November for the doubling (to 20 percent) of the payments individuals currently contribute toward their own medical care. The Medical Insurance Council also called for patients of 70 years and older to be charged in proportion to the cost of their treatment. Older patients currently pay a flat rate of 710 yen (US\$6.25) a day for hospitalization and 1,020 yen $(\$ 9.00)$ a month for outpa-tient services. This amounts to only about 5 percent of their total treatment costs, but the council wants to increase this to between on the same day as Koyama). Several other bureaucrats are also implicated in the widening scandal. In addition, senior politicians (including Ryutaro Hashimoto, Japan's Prime Minister) are also reported to have received donations from Aya Fukushi Group associates.

The alleged bribery involves subsidies provided under the "Gold Plan" - a tenyear government plan to promote health and welfare for the elderly. The plan was launched when Okamitsu headed the health ministry's department for health and welfare for the aged in the early 1990s. Under the Gold Plan, which is designed to promote and improve care for the elderly, central government subsidies meet 50 percent of the construction costs of new nursing homes, with local governments contributing a further 25 percent. Companies are also entitled to apply for generous subsidies to help with the day-to-day costs of running a nursing home. It is alleged that Okamitsu used his considerable influence at the ministry to win substantial subsidies for the Aya Fukushi Group under the Gold Plan.

Japan has the world's longest life expectancy ( 83 years for women, 77 for men) and is already spending more than a third of its medical care expenses (currently seven percent of the national income) on care for the elderly. Furthermore, the number of individuals over the age of 65 is blood scandal (Nature Medicine 2, 498; 1996) and is now the focus of intensifying criticism and anger because of the new scandals. Police raided the ministry in December for an unprecedented second time in a year. Ironically, Okamitsu was given the ministry's top post in July last year in order to launch reforms of the already discredited ministry. Analysts are concerned that the ministry no longer has the authority needed to push through health-care reforms.

Politicians and ministry officials acknowledge the difficulties they face, but intend to press ahead with reform. "It is regrettable that we have lost the nation's faith in the administration of public health and welfare," Junichiro Koizumi, Japan's new Minister of Health and Welfare recently told the Japanese Diet (parliament). Other senior politicians are equally concerned about the potential fallout from these continuing scandals "Public trust in the whole administration has fallen to the ground," Chief Cabinet Secretary Seiroku Kajiyama said at a press conference following Okamitsu's arrest.

Masanori Fukushima, a long-time advocate for reform of Japan's medical care system, describes the ministry as "a cradle of crime," but thinks it is inevitable that Japanese people will have to pay more in the long run.

RICHARD NATHAN Tokyo, Japan lation, is still the target of heavy public criticism following the HIV-contaminated

10 and 20 percent. New legislation based on these proposals is expected this year.

However, any new legislation may have difficulty passing, as the ministry, which would normally champion the new legis-

\section{Genset and China a genetic pair}

The French genomics company Genset SA has announced plans to set up a joint venture with the Chinese Academy of Medical Sciences in Beijing to look for genes related to common diseases. Under the deal, DNA will be collected from related and unrelated individuals suffering from cardiovascular diseases and cancer, and will be analyzed at Genset's facilities in France. The eventual aim is to market treatments in China based on any discoveries from the research.

"What is very important in this collaboration is that in China you can get access to large and very homogeneous groups," said Pascal Brandys, president and chief executive officer of Genset. "This homogeneity, plus Genset's advanced technology, will make mapping three times faster, cutting the time from 18 months to three months."

Ba Denian, president of the Chinese
Academy, which has a network of more than 25 research institutes and hospitals across the country, says that the Chinese researchers "view genomics research as extremely important for Chinese healthcare in the twenty-first century, and we are also convinced that our joint effort will lead to fundamental discoveries which will benefit not only China, but the rest of the world."

Despite hopeful words on both sides, this deal comes amidst concerns over a Chinese law introduced in June 1995, that many believe to be eugenic in nature. Two articles in particular of the Law on Maternal and Infant Healthcare, are causing disquiet. Article 10 says "Physicians shall, after performing the premarital physical check-up, explain and give medical advice to both the male and female who have been diagnosed with certain genetic disease of a serious nature which is consid- 